\title{
Age of the coal accumulation in the Irkutsk Basin based on accessory zircon dating in the Azeisk deposit tonstein $(\mathrm{LA}-\mathrm{ICP}-\mathrm{MS})^{*}$
}

\author{
E. A. Mikheeva ${ }^{1}$, E.I. Demonterova ${ }^{1}$, V.B.Khubanov ${ }^{2}$, A. V. Ivanov ${ }^{1}$, \\ A. V.Arzhannikova', S. G. Arzhannikov' ${ }^{1}$, A. V. Blinov ${ }^{3}$ \\ ${ }^{1}$ Institute of the Earth's Crust of the Siberian Branch of the Russian Academy of Sciences, \\ 128, ul. Lermontova, Irkutsk, 664033, Russian Federation \\ ${ }^{2}$ Geological Institute of the Siberian Branch of the Russian Academy of Sciences, \\ 6A, ul. Sakhyanova, Ulan-Ude, 670047, Russian Federation \\ ${ }^{3}$ Vinogradov Institute of Geochemistry of the Siberian Branch of the Russian Academy of Sciences, \\ 1A, ul. Favorskogo, Irkutsk, 664033, Russian Federation
}

For citation: Mikheeva E. A., Demonterova E. I., Khubanov V.B., Ivanov A. V., Arzhannikova A. V., Arzhannikov S. G., Blinov A. V. (2020). Age of the coal accumulation in the Irkutsk Basin based on accessory zircon dating in the Azeisk deposit tonstein (LA-ICP-MS). Vestnik of Saint Petersburg University. Earth Sciences, 65 (3), 420-433. https://doi.org/10.21638/spbu07.2020.301

The Irkutsk Coal Basin is located in the south of the Siberian Platform. The deposits of the basin are represented by Jurassic continental sediments. Since the 1970s, tuffs and tuffaceous rocks have been found in sediments of the Irkutsk Coal Basin, but so far only fragmentary information has been available on them. Previously, the age of sediments in the Irkutsk Basin was determined by the biostratigraphic method. We studied a section of the Cheremkhovo Fm., the most ancient formation of the basin, at the Azeisk coal deposit (in the area of the town of Tulun) with the aim of obtaining a geochronological constraints on the timing of sedimentation. The paper shows that tonsteins, which are transformed to clay ash-fall layers within coals, are suitable for radioisotope dating by accessory zircons. U-Pb dating of accessory zircons in tonstein from an industrial coal seam was performed using the LA-ICP-MS method. The obtained U-Pb age of $187.44+0.45-1.60 \mathrm{Ma}$, falling into the Pliensbachian Age, indicates the period of maximum coal formation in the Irkutsk Basin. This is the first radiometric age determination for the timing of accumulation of coal in the Irkutsk Basin. In the context of paleogeographic reconstructions, this age determines the upper limit of the tectonic quiescence period, which created conditions for lacustrine-boggy sedimentation in the vast territory of the Irkutsk Basin.

Keywords: Jurassic Period, volcanism, tonstein, Irkutsk coal Basin, accessory zircons, U-Pb dating.

* This work was supported by a grant from the RFBR (Russian Foundation for Basic Research) (Project No. 18-35-00216). The U-Pb isotope geochronological studies were performed at the Analytical Center for Mineralogical, Geochemical, and Isotope Research of the GI SB RAS in Ulan-Ude (Base Project IX.129.1.2., State Registration Number AAAA-A16-116122110027-2).

() Санкт-Петербургский государственный университет, 2020 


\section{Introduction}

The Irkutsk Coal Basin is located in the south of the Siberian Craton (Fig. 1). The deposits of the basin are represented by Jurassic continental-type sediments. A valid regional stratigraphic scale was adopted in 1981, with the distinguishing of the Cheremkhovo (Pliensbachian - early Toarcian), Prisayan (Toarcian - Aalenian) and Kuda (conditionally Aalenian) Fms. (Saks et al., 1981). According to the valid scheme, the studied Cheremkhovo Fm. is divided into three members: Member I, Member II, and Member III. However, according to other studies, the Cheremkhovo Fm. should be considered an indivisible macro-rhythm to the only exclusion of Member III (Panaev, 1968; Panaev and Nikitina, 1970; Skoblo et al., 2001). Skoblo et al. (2001) also propose that members of the Cheremkhovo Fm. should be considered sub-formations. In this paper, we consider the Cheremkhovo Fm. as consisting of two sub-formations - the lower and the upper (Fig. 2).

Despite the large number of publications devoted to studies of the Irkutsk Basin (Adamenko et al., 1971; Akulov et al., 2015; Feinstein, 1971; Kiritchkova et al., 2017; Odintsov, 1967; Skoblo et al., 2001; Timofeev, 1970), questions related to the age and position of the stratigraphic units still remain undetermined (Fig. 2). The age of the Irkutsk Basin sediments was determined by the biostratigraphic method, which gives a rather wide time interval. While the lower limit of the sedimentation onset is determined in the Pliensbachian Age (Akulov et al., 2015; Kiritchkova et al., 2017; Saks et al., 1981; Skoblo et al., 2001), the upper one drifts from the Aalenian to the Bajocian Age (Akulov et al., 2015;

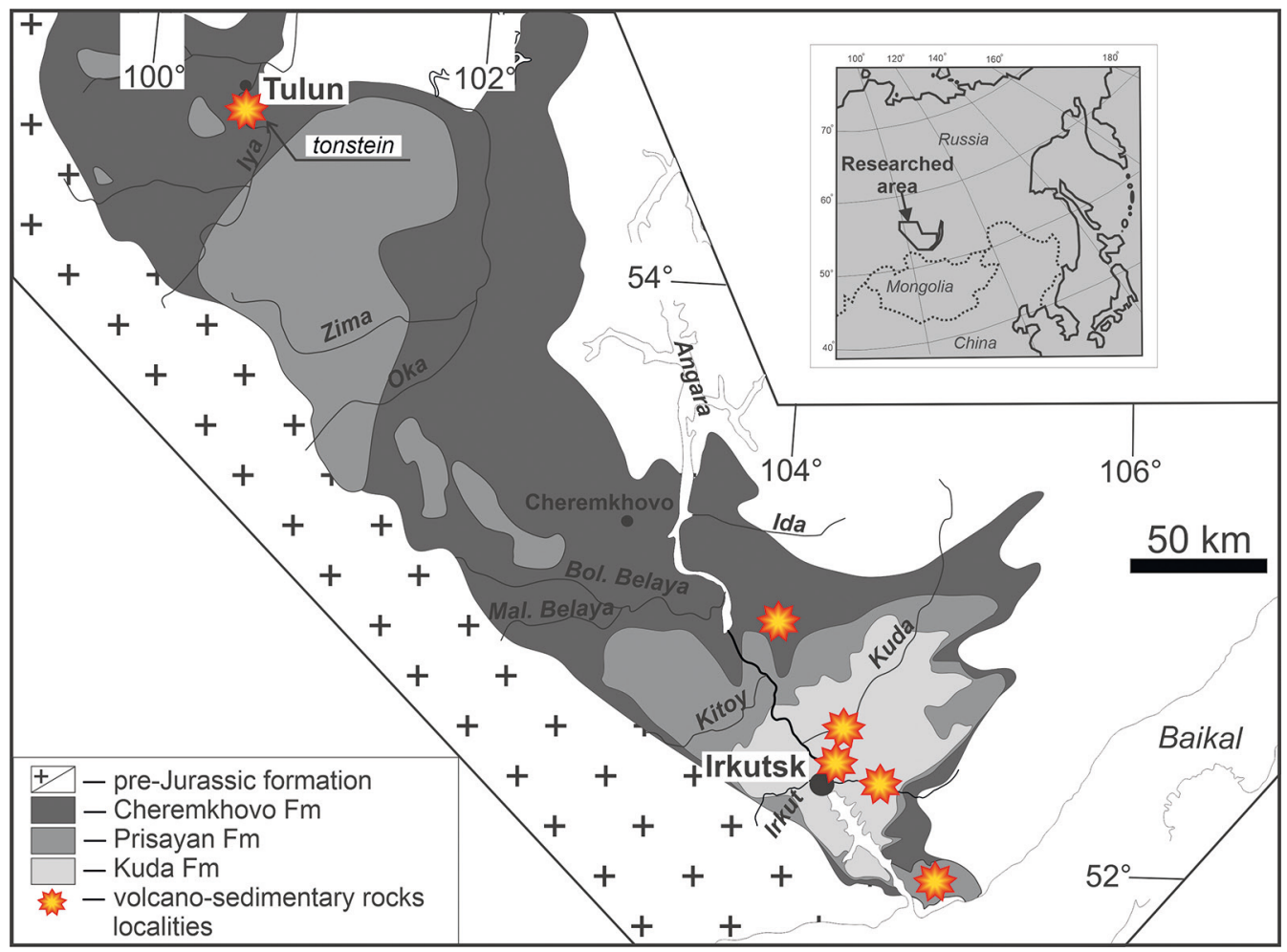

Fig. 1. Simplified geological map of the Irkutsk Basin and volcano-sedimentary rocks localities. Author's drawing 


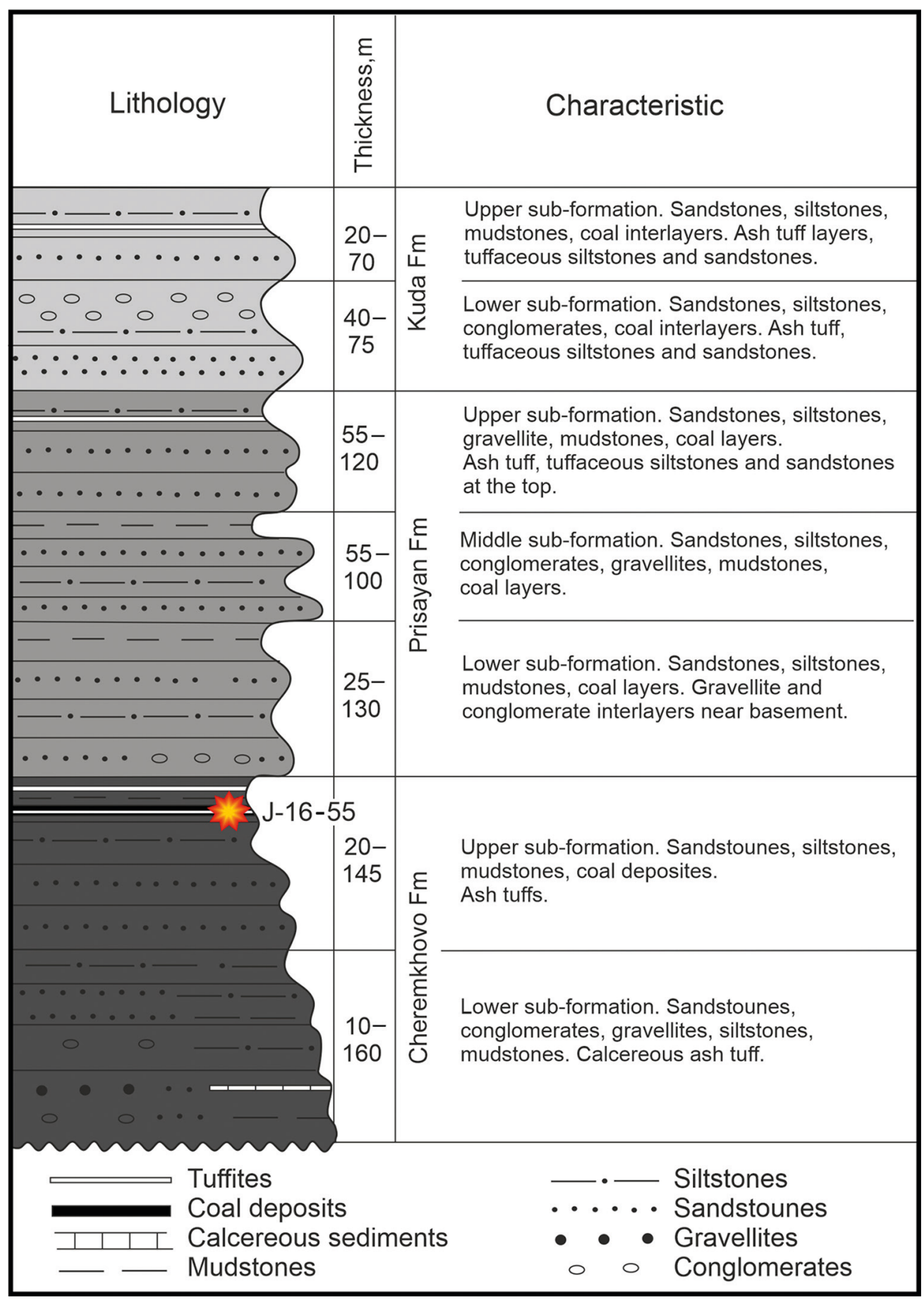

Fig. 2. Composite stratigraphic column for the Irkutsk Basin, modified after (Anonymous, 1981; Skoblo et al., 2001) 
Kirichkova et al., 2016; Saks et al., 1981; Skoblo et al., 2001). The age of the sediments was determined mainly by plant residues (Frolov and Mashchuk, 2014; 2018; Kirichkova and Travina, 2000); fauna findings are rare and are mainly related to the lower sub-formation of the Prisayan Fm. (Saks et al., 1981; Skoblo et al., 2001).

At different times, tuffs and tuffaceous rocks were found in the sediments of the Irkutsk Coal Basin (Admakin and Portnov, 1987; Arbuzov et al., 2016; Kiziyarov and Meshalkin, 1978; Meshalkin et al., 1983; Rybakov and Hobotova, 1999; Skoblo et al., 2001). They were first discovered in the 1970s according to drilling results (Kiziyarov and Meshalkin, 1978; Meshalkin et al., 1983). Tuff and tuffaceous rock horizons are observed in the sediments of all formations (Fig. 2). Usually, they occur in the form of lenses, interlayers, and horizons with a maximum thickness of up to $18 \mathrm{~m}$ (Skoblo et al., 2001) and are most widespread in the southeastern part of the Irkutsk Basin (Fig. 1). They are represented by vitric tuffs, tuff siltstones, and tuff sandstones; according to geological survey data, there are found mainly in drill cores (Saks et al., 1981). Such rocks attain their greatest thicknesses in the upper part of the Jurassic section, namely, in the Prisayan and Kuda Fms. There is evidence of the presence of tuffaceous interlayers in the Cheremkhovo Fm. sediments (Arbuzov et al., 2016; Kiziyarov and Meshalkin, 1978).

This work investigates an ash interlayer (tonstein) in an industrial coal seam of the Azeisk deposit in the area of Tulun (Fig. 1). The research by Arbuzov et al. (2016) substantiated the volcanic origin of clay layers in coal, which were formed due to the transformation of felsic pyroclastic material (Arbuzov et al., 2016). This paper presents the data of $\mathrm{U}-\mathrm{Pb}$ dating of accessory zircons from tonstein. The LA-ICP-MS U-Pb dating method was used to estimate the tonstein age, because felsic volcanic ash contains accessory zircon grains in addition to detrital ones. This method makes it possible to analyze a large number of grains, which is important for obtaining a sufficiently large cluster in calculating the age and can be used for dating of ash-fall.

\section{Geological description}

The Cheremkhovo Fm. is known throughout the limits of the Irkutsk Coal Basin. The formation is composed of terrigenous deposits with coal seams of industrial thickness; the thickness of the formation varies from 30-100 to 180-240 m. Within the basin, three groups of facies are distinguished for the Cheremkhovo Fm.: the alluvial, the alluvial-deluvial, and the floodplain (Odintsov, 1967; Timofeev, 1970). Most of the basin is encompassed by alluvial facies, which are represented in the southeast by foothill alluvium facies (the lower sub-formation). By the end of the accumulation of the lower sub-formation, the distribution contours of foothill alluvium conglomerates become significantly narrower. Alluvial-deluvial facies take the central part of the basin and give place to lacustrine-boggy facies by the end of the upper sub-formation accumulation. Floodplain facies are typical in the northern and northwestern parts of the basin and alternate with channel ones. All industrial coal deposits known in the Irkutsk Basin are associated with the upper sub-formation of the Cheremkhovo Fm. The number of coal seams and interlayers there varies from 1 to 16 individual seams and attains a thickness of $14 \mathrm{~m}$ (Cherepovskij, 2002; Skoblo et al., 2001).

In this work, we investigate a section of the Cheremkhovo Fm. at the Azeisk coal deposit located in the area of the town of Tulun (Fig. 1). The deposits here are represented 

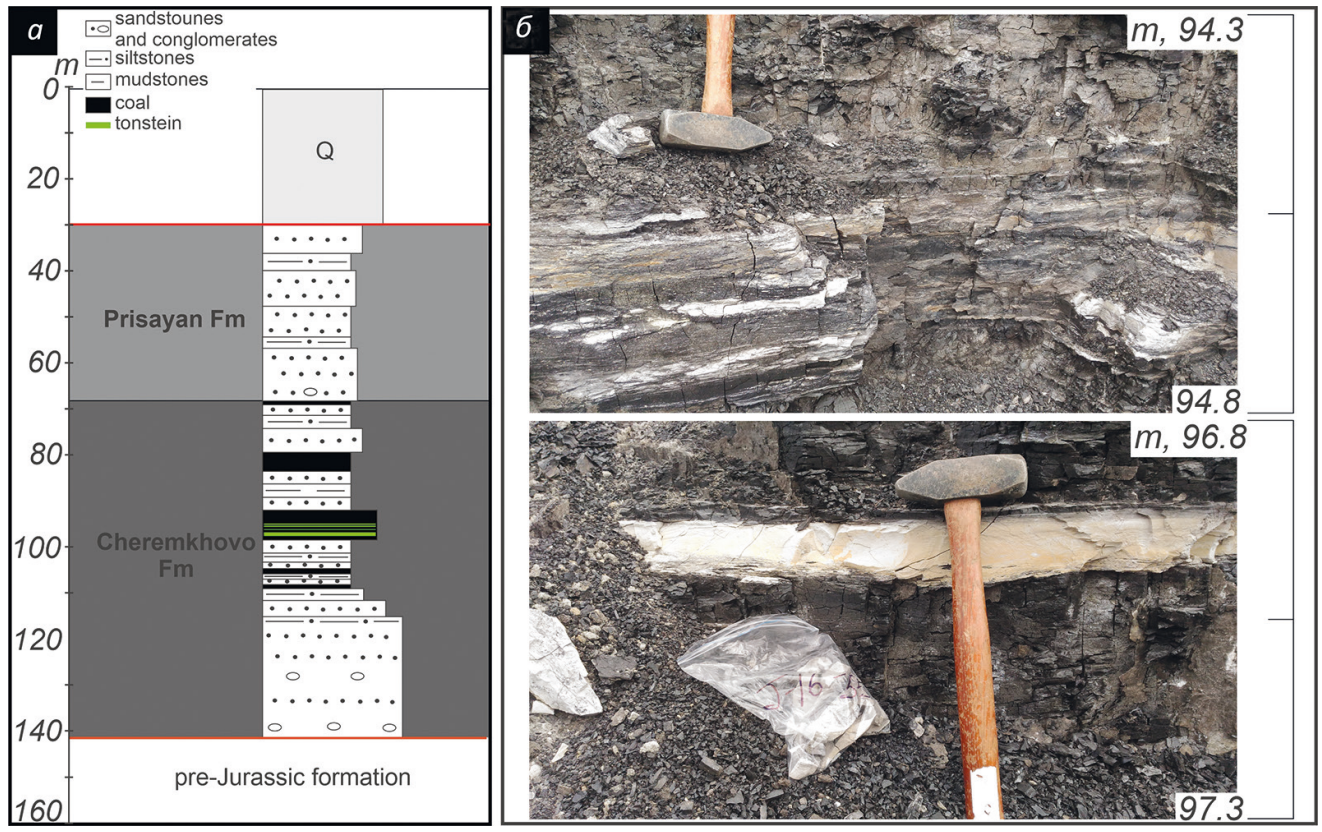

Fig. 3. (a) Composite stratigraphic column for the Jurassic sediments in the area of the Azeisk deposit (Cherepovsky, 2002; Arbuzov et al., 2016); (b) Photographs of the tonsteins at the Azeisk deposit

by poorly consolidated fine- to medium-grained sandstones, siltstones, mudstones, and coals of the Cheremkhovo Fm. upper sub-formation (Fig. 3, a). Two mature, productive coal seams (II and I) are distinguished in the studied section. Seam II, which is pervasive, is the most mined (its average thickness is $\sim 6 \mathrm{~m}$ ) (Arbuzov et al., 2016; Cherepovskij, 2002). In Seam II, clay interlayers from white to grayish-white stand sharply apart against the background of coal (Fig. 3, b); they are less than $0.3 \mathrm{~m}$ thick and more than $4 \mathrm{~km}$ long. These interlayers were studied in detail in the paper by Arbuzov et al. (2016), and it was found that they almost entirely consisted of kaolinite with the participation of quartz, cristobalite, illite, and feldspars; accessory minerals are represented by zircon, monazite, and sulfides. Based on the occurrence conditions, composition, and geochemical features, the authors call these interlayers tonsteins and confirm their pyroclastic nature (Arbuzov et al., 2016).

Deposited in marine conditions, volcanic ash usually transforms into clay deposits known as bentonites (consisting mainly of montmorillonite or illite), whereas the Irkutsk Basin deposits are continental type sediments. The most suitable environment for the conservation of volcanic ash-fall material under continental conditions is shallow lakes, ponds, and swamps (Bohor and Triplehorn, 1993; Spears, 2012), i. e., the coal-forming environment of the Cheremkhovo Fm. is the most favorable. In coal-bearing rocks, layers of volcanic ash mainly form clays known as tonstein, which are characterized by a high content of kaolinite formed as a result of devitrification of volcanic glass fragments (Bohor and Triplehorn, 1993; Spears, 2012). It is generally accepted that tonsteins form as a result of volcanic ash transformation in situ (in swamp or lake environments), which was deposited when air masses transported ash emissions of powerful eruptions over long distances 
with the participation of felsic magma (Triplehorn, 1990). It should be noted that at the present time there is a large number of papers, both on identification of tonsteins - in the understanding of their igneous nature (Anggara et al., 2018; Arbuzov et al., 2016; Dai et al., 2011; Jurigan et al., 2019) - and on dating such layers (Ducassou et al., 2019; GuerraSommer et al., 2008; Jurigan et al., 2019).

\section{Analytical procedures}

Material from the tonsteins was studied by $\mathrm{X}$-ray powder diffraction analysis using a DRON-3.0 diffractometer (Burevestnik, Russia) at the Centre for Geodynamics and Geochronology (CGG) of the Institute of the Earth's Crust (IEC) of the Siberian Branch of the Russian Academy of Sciences (SB RAS) (analyst - M. N. Rubtsova). To determine the mineralogical composition, we selected six clay layers from the coal seam being mined that potentially correspond to tonsteins. To determine the mineral composition, the samples were triturated in an agate mortar with alcohol and studied by powder diffraction technique. Acquisition conditions: emission $-\mathrm{CuKa}, \mathrm{Ni}-$ filter, $\mathrm{V}=25 \mathrm{kV}$, $\mathrm{I}=20 \mathrm{~mA}$, step angle $-0.05^{\circ}$. To identify clay minerals, oriented sample material was prepared by depositing a clay fraction on a glass plate, heating at $550{ }^{\circ} \mathrm{C}$ for 3 hours, and saturation with ethylene glycol (Brown, 1965). The radiographs were identified using a phase search program. The semiquantitative component ratio was calculated using corundum numbers (RIR values) (Hubbard and Snyder, 1988). The phase proportions obtained are approximate.

Zircon grains were extracted from the most representative tonstein sample (J-16-55) following a classical mineral separation procedure and handpicked under a binocular microscope. After embedding the grains in an epoxy resin, the pucks were polished down to reveal the grain through their centers. The $\mathrm{U}-\mathrm{Pb}$ zircon dating was performed by LA-SF-ICP-MS in the Analytical Center for Mineralogical, Geochemical, and Isotope Research of the Geological Institute SB RAS (Ulan-Ude). Zircon grains were extracted from the tonstein sample, following a classical mineral separation procedure. Analyzed crystal size varied between 60 and $180 \mu \mathrm{m}$. U-Pb dating was performed using ICP-MS Element XR (ThermoFisher Scientific) coupled to an UP-213 laser ablation system (New Wave Research). The laser beam was $40-50 \mu \mathrm{m}$ in diameter, the fluency was about $3.5 \mathrm{~J} / \mathrm{cm}^{2}$, the total time of laser radiation was $55 \mathrm{~s}$. Helium was used as a carrier gas; it was mixed with argon. The 91500 , Plešovice and GJ-1 were used as external standards. Primary ages were calculated relative to the 91500 standard. The measurement data were processed using the GLITTER (Griffin, 2008), IsoplotR (Vermeesch, 2018) and ISOPLOT (Ludwig, 2012) software. The instrumental parameters and measurement technique are described in more detail by Buyantuev et al. (2017) and Khubanov et al. (2016).

\section{Results}

Among six clay layers analyzed by XRD, only one sample corresponded to "pure" tonstein, mainly composed of kaolinite (up to $95 \%$, Fig. 4). In addition, five clay layers are considered as "mixed" tonsteins, consisting of a mixture of volcanic ashes (represented by kaolinite) and detrital particles (15-70\%). These layers present traces of quartz, feldspars 


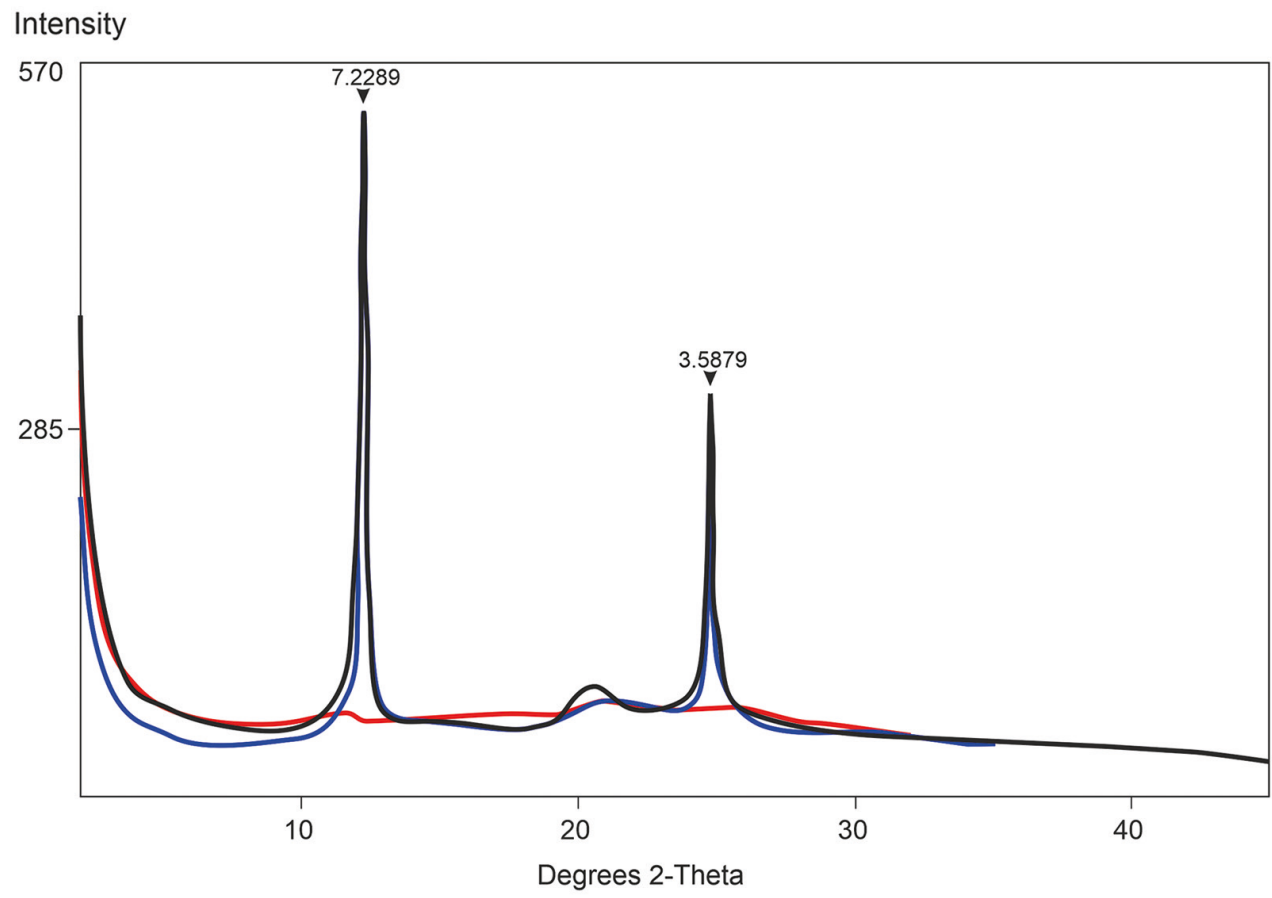

Fig. 4. XRD diffractogram showing a pure tonstein (J-16-55). Black, blue and red lines are for air dry, glycolated solvation and heated conditions, respectively

and illite. The "pure" tonstein was selected for geochronological analysis. Its location is reported in Figs. 1 and 2. In total, 110 zircon grains were analyzed. The size of the zircon grains is small $(50 \mu \mathrm{m}$ on average, up to $150 \mu \mathrm{m})$. Most of the grains are euhedral and elongated, less than $30 \%$ are isometric and represented by fragments of elongated grains. Zircon grains are colorless and non-rounded.

Results of $\mathrm{U}-\mathrm{Pb}$ dating of zircon are shown in Fig. 5. Data from zircon analyses are provided in Supplement $1^{1}$. The first step consists in filtering the data based on their probability of concordance, calculated using IsoplotR (Vermeesch, 2018), by comparing ${ }^{206} \mathrm{~Pb} /{ }^{238} \mathrm{U}$ and ${ }^{207} \mathrm{~Pb} /{ }^{235} \mathrm{U}$ ratios including the decay constant errors (Ludwig, 1998; Nemchin and Cawood, 2005). The cut-off level applied to filter the data was $10 \%$. For the next step, only concordant data were considered. Then where calculated concordant age, reduced chi-squared (MSWD), and p-value for concordance for each analysis to assess of the data using IsoplotR (Vermeesch, 2018). Depositional age was calculated as the concordia age using IsoplotR (Vermeesch, 2018).

We used the Tuff Zirc algorithm (Ludwig and Mundil, 2002), implemented as the "zircon age extractor" tool in Isoplot/Ex 4.15 (Ludwig, 2012). This algorithm was developed to minimize the effects of both inheritance and $\mathrm{Pb}$ loss, by isolating the largest cluster of analyses yielding a probability of fit $>0.05$, and calculating the median age of this cluster. The uncertainties are asymmetric and provided a $95 \%$ confidence limit. The TuffZirc algorithm was applied to the concordant ages (i. e., obtained using the "concordia" function).

${ }^{1}$ Supplement 1 (supplement are given in the original edition) can be found at the website: https:// escjournal.spbu.ru/article/view/6556/5691 

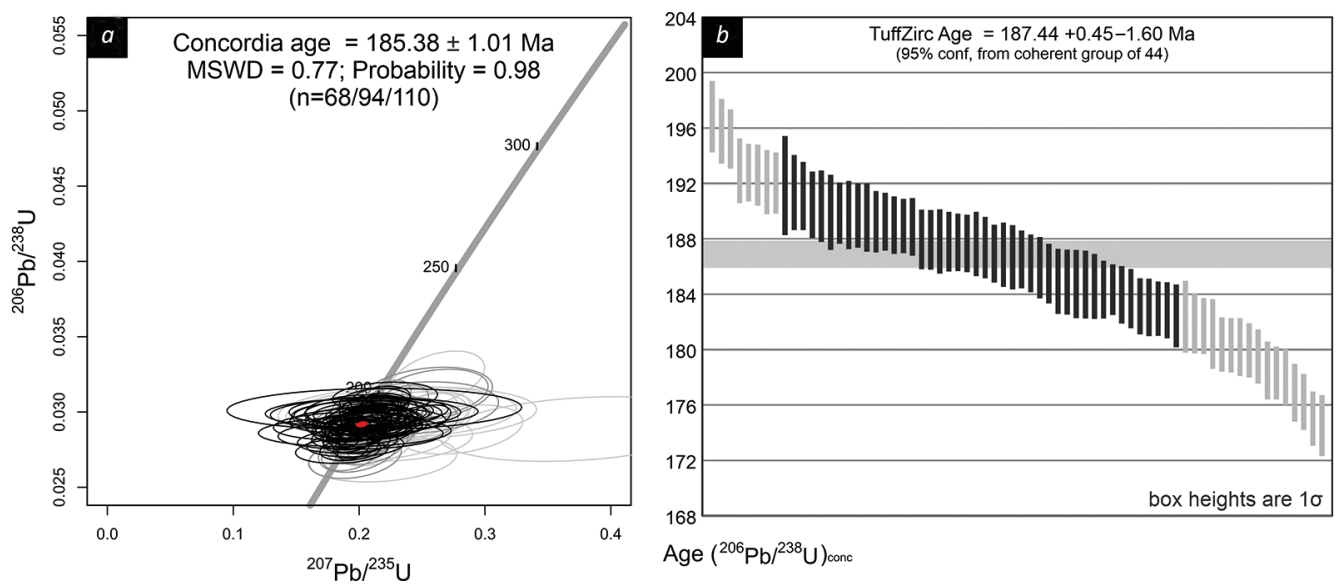

Fig. 5. U-Pb data for zircon grains of the sample J-16-55

(a) Concordia diagram. Age, MSWD and probability are for the concordant grains with discordance of less than $10 \% . \mathrm{N}$ is for the number of filtered zircon analyses from which concordia age was calculated (shown by black ellipses) / the number of concordant data with the discordance of $>10 \%$ (shown by dark grey ellipses) / total number of zircon analyses (light grey ellipses for all other analyses).

(b) Results provided by the TuffZirc algorithm applied to the concordant zircon ages: the data selected and rejected to calculate the TuffZirc dates are shown in black and light grey respectively; the grey area correspond to the TuffZirc date and its calculated error.

In the dated sample, 68 out of 110 analyzed zircon grains are used for calculation (Fig. 5, a). For example, the data spread along the concordia curve and conform to a single population. The depositional age is $185.38 \pm 1.01 \mathrm{Ma}(\mathrm{MSWD}=0.77$; Fig. $5, a)$. The dispersion of data along the concordia curve shows that either zircon grains represent a mixture of different ages or were affected by minor radiogenic lead loss or both and therefore that the depositional age might be slightly older. The TuffZirc algorithm provides a date of $187.44+0.45-1.60 \mathrm{Ma}$ (Fig. 5, b). This value $187.44+0.45-1.60 \mathrm{Ma}$ is taken for the time of a distant volcanic eruption, which leads to formation of an ash-fall layer later transformed into tonstein. Within an error of the age determination, this marks the timing of accumulation of coal-bearing sediments of the upper sub-formation of the Cheremkhovo Fm. of the Irkutsk Basin.

\section{Discussion}

The pyroclastic nature of the studied clay interlayers is determined, first of all, by their appearance - thin, well lithified layers, almost white (Fig. 3, $b$ ), and of great length, up to $4 \mathrm{~km}$. To ensure that the obtained $\mathrm{U}-\mathrm{Pb}$ age corresponds to the age of sedimentation, it must be ascertained that the volcanic ash was not reworked and no detrital zircon was introduced. The mineral and chemical composition of Azeisk tonsteins has been studied in detail (Arbuzov et al., 2016; Ilyenok, 2018). The rock-forming minerals in tonsteins are represented by kaolinite, quartz, cristobalite, illite, and feldspars, and the accessory minerals are represented by zircon, monazite, baddeleyite, bastnasite, uranium oxide minerals, as well as by native minerals of gold, silver, nickel, zinc, tungsten, silicon, and intermetallic compounds in insignificant concentrations (Arbuzov et al., 2016). Thus, the authors 


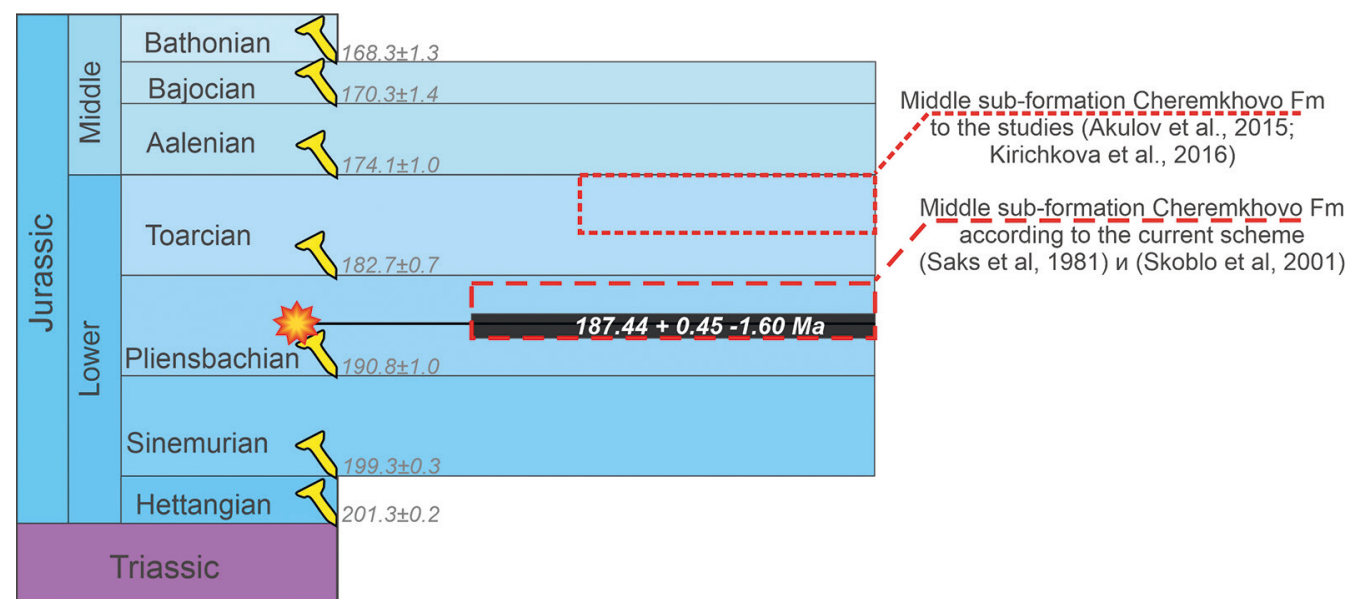

Fig. 6. U-Pb age of the accumulation of the coal-bearing sediments in the Irkutsk basin based on accessory zircon dating in the Azeisk deposit tonstein in comparison with recent studies (Skoblo et al., 2001; Akulov et al., 2015; Kirichkova et al., 2016). Preliminary data on calculated U-Pb age for the lower and upper limits of sedimentation in the Irkutsk Basin are indicated

confirm the pyroclastic nature of the initial matter of the tonsteins, and, based on the data obtained, indicate the felsic (rhyolite) composition of the initial igneous material (Arbuzov et al., 2016).

The upper Cheremkhovo Fm. marks the lacustrine-boggy sedimentation in the vast territory of the Irkutsk Basin. It was established that there was coarsening of sediments upward through the Prisayan and Kuda Fm. Such upward coarsening, together with an increase of ${ }^{143} \mathrm{Nd} /{ }^{144} \mathrm{Nd}$ ratios and an increase of the Jurassic-age population of detrital zircon grains, was associated with the closure of the Mongol-Okhotsk Ocean, the collision of two continental blocks and an orogenic belt formation (Arzhannikova et al., 2020; Demonterova et al., 2017). Within this geodynamic scheme, the age of the upper Cheremkhovo Fm. places the upper limit of the tectonic quiescence period before the intensification of tectonic processes in the southern mobile framing of the Siberian Platform.

In the context of regional stratigraphy, the obtained age of $187.44 \mathrm{Ma}$ is consistent with the valid stratigraphic scheme (Saks et al., 1981) and the research of Skoblo et al. (2001) that supplements it (Fig. 6). An alternative age for the Cheremkhovo Fm. was proposed by Akulov et al. (2015) and Kirichkova et al. (2016; 2017). In these papers, the age of the upper sub-formation of the Cheremkhovo Fm. falls into the Toarcian (Fig. 6). However, this contradicts the $\mathrm{U}-\mathrm{Pb}$ dating of tonstein provided in this study. It should be noted that the stratigraphy of the Jurassic Age of the Irkutsk Basin is mainly based on palynological data (Saks et al., 1981; Skoblo et al., 2001), and recent papers (Akulov et al., 2015; Kirichkova et al., 2016; Kiritchkova et al., 2017) are the result of phytostratigraphic research. Thus, palynological data provide more robust constraints on the age of the Jurassic continental deposits, at least for the Irkutsk Basin. 


\section{Conclusions}

The age of coal-bearing deposits of the Cheremkhovo Fm. represented at the Azeisk coal deposit was established as $\sim 187 \mathrm{Ma}$ using the LA-ICP-MS U-Pb method on accessory zircons from tonstein. This is the first radiometric age determination for the timing of accumulation of coal-bearing sediments in the Irkutsk Basin.

In the context of paleogeographic reconstructions, this age determines the upper limit of the tectonic quiescence period, which created conditions for lacustrine-boggy sedimentation in the vast territory of the Irkutsk Basin. The coarsening of sediments in the overlying Prisayan and Kuda Fm. indicates the intensification of relief formation processes on the border with the Siberian Craton associated with the formation and development of the Mongol-Okhotsk orogenic belt.

\section{References}

Adamenko, O. M., Dolgushin, I. Yu., Ermolov, V. V., Isaeva, L. L., Kozlovskaya, S. F., Leonov, B. N. and Cejtlin, S. M. (1971). Highlands and lowlands of Eastern Siberia. Moscow: Nauka Publ. (In Russian)

Admakin, L. A. and Portnov, A. G. (1987). Tonsteins of Irkutsk basin. Lithol. Miner. Resour., 88-98. (In Russian)

Akulov, N. I., Frolov, A. O., Mashchuk, I. M. and Akulova, V. V. (2015). Jurassic Deposits of the Southern Part of the Irkutsk Sedimentary Basin. Stratigr. Geol. Correl., 23, 387-409. https://doi.org/10.1134/ s0869593815040036

Anggara, F., Amijaya, D. H., Harijoko, A., Tambaria, T. N., Sahri, A. A. and Ma, Z. A. N. (2018). Rare earth element and yttrium content of coal in the Banko coalfield, South Sumatra Basin, Indonesia: Contributions from tonstein layers. Int. J. Coal Geol., 196, 159-172. https://doi.org/10.1016/j.coal.2018.07.006

Arbuzov, S. I., Mezhibor, A. M., Spears, D. A., Ilenok, S. S., Shaldybin, M. V. and Belaya, E. V. (2016). Nature of tonsteins in the Azeisk deposit of the Irkutsk Coal Basin (Siberia, Russia). Int. J. Coal Geol., 153, 99-111. https://doi.org/10.1016/j.coal.2015.12.001

Arzhannikova, A. V., Demonterova, E. I., Jolivet, M., Arzhannikov, S. G., Mikheeva, E. A., Ivanov, A. V., Khubanov, V. B. and Pavlova, L. A. (2020). Late Mesozoic topographic evolution of western Transbaikalia: Evidence for rapid geodynamic changes from the Mongol-Okhotsk collision to widespread rifting. Geosci. Front., 11, 1695-1709. https://doi.org/10.1016/j.gsf.2019.12.012

Bohor, B.F. and Triplehorn, D. M. (1993). Tonsteins: altered volcanic ash layers in coal-bearing sequences. Geological Society of America.

Brown, G. (ed.) (1965). X-ray methods of studying the structure and clay minerals. Moscow: Mir Publ. (In Russian)

Buyantuev, M.D., Khubanov, V. B. and Vrublevskaya, T. T. (2017). U-Pb LA-ICP-MS dating of zircons from subvolcanics of the bimodal dyke series of the western Transbaikalia: technique, and evidence of the late paleozoic extension of the crust. Geodyn. Tectonophys., 8, 369-384. https://doi.org/10.5800/gt2017-8-2-0246 (In Russian)

Cherepovskij, V.F. (ed.) (2002). The Coal Resources of Russia, vol. 3. Moscow: Geoinformcentre Publ. (In Russian)

Dai, S. F., Wang, X. B., Zhou, Y.P., Hower, J.C., Li, D.H., Chen, W.M., Zhu, X. W. and Zou, J.H. (2011). Chemical and mineralogical compositions of silicic, mafic, and alkali tonsteins in the late Permian coals from the Songzao Coalfield, Chongqing, Southwest China. Chem. Geol., 282, 29-44. https://doi. org/10.1016/j.chemgeo.2011.01.006

Demonterova, E.I., Ivanov, A.V., Mikheeva, E. M., Arzhannikova, A.V., Frolov, A. O., Arzannikov, S.G., Bryanskiy, N. V. and Pavlova, L. A. (2017). Early to Middle Jurassic history of the southern Siberian continent (Transbaikalia) recorded in sediments of the Siberian Craton: Sm-Nd and U-Pb provenance study. Bull. Soc. géol. Fr., 188, 1-29. https://doi.org/10.1051/bsgf/2017009

Ducassou, C., Mercuzot, M., Bourquin, S., Rossignol, C., Pellenard, P., Beccaletto, L., Poujol, M., Hallot, E., Pierson-Wickmann, A. C., Hue, C. and Ravier, E. (2019). Sedimentology and U-Pb dating of Carboniferous to Permian continental series of the northern Massif Central (France): Local palaeogeographic 
evolution and larger scale correlations. Palaeogeogr. Palaeoclimatol. Palaeoecol., 533, 109228. https:// doi.org/10.1016/j.palaeo.2019.06.001

Feinstein, G. K. (1971). Jurassic paleogeography of the Irkutsk amphitheatre in relation to its exogenic ore bearance. In: Materialy po geologii i poleznym iskopaemym Sibirskoi platformy. Moscow: Nedra Publ., 55-68. (In Russian)

Frolov, A. O. and Mashchuk, I. M. (2018). Jurassic flora and vegetation of the Irkutsk Coal Basin. Irkutsk: Institut geografii im. V. B. Sochavy SO RAN Press. (In Russian).

Frolov, A. O. and Mashchuk, I. M. (2014). Field atlas of the Jurassic flora of the Irkutsk coal basin. Irkutsk: Institut zemnoi kory SO RAN Press. (In Russian)

Griffin, W. L. (2008). GLITTER: data reduction software for laser ablation ICP-MS. Laser Ablation ICP-MS Earth Sci. Curr. Pract. Outst. issues, 308-311.

Guerra-Sommer, M., Cazzulo-Klepzig, M., Formoso, M. L. L., Menegat, R. and Fo, J. G. M. (2008). U-Pb dating of tonstein layers from a coal succession of the southern Parana Basin (Brazil): A new geochronological approach. Gondwana Res., 14, 474-482. https://doi.org/10.1016/j.gr.2008.03.003

Hubbard, C. R. and Snyder, R.L. (1988). RIR-measurement and use in quantitative XRD. Powder Diffr., 3, 74-77.

Jurigan, I., Ricardi-Branco, F., Neregato, R. and dos Santos, T.J.S. (2019). A new tonstein occurrence in the eastern Parana Basin associated with the Figueira coalfield (Parana, Brazil): Palynostratigraphy and U-Pb radiometric dating integration. J. South Am. Earth Sci., 96, 102377. https://doi.org/10.1016/j. jsames.2019.102377

Khubanov, V.B., Buyantuev, M.D. and Tsygankov, A. A. (2016). U-Pb dating of zircons from PZ3-MZ igneous complexes of Transbaikalia by sector-field mass spectrometry with laser sampli ng: technique and comparison with SHRIMP. Russ. Geol. Geophys., 57, 190-205. https://doi.org/10.1016/j.rgg.2016.01.013

Kirichkova, A. I., Kostina, E. I. and Nosova, N. V (2016). Continental Jurassic sratigraphy of Irkutsk amphitheater. Neft. Geol. Teor. i Pract., 11, 1. (In Russian)

Kirichkova, A. I. and Travina, T. A. (2000). Phytostratigraphy of Jurassic coal-bearing deposits of the Irkutsk basin. Stratigr. Geol. Correl., 8, 89-102. (In Russian)

Kiritchkova, A.I., Kostina, E.I. and Nosova, N. V. (2017). Jurassic continental deposits in the sections of the Irkutsk Coal Basin stratoregion. Stratigr. Geol. Correl., 25, 492-514. https://doi.org/10.1134/ s0869593817050033

Kiziyarov, G. P. and Meshalkin, S. M. (1978). First find of volcanic tuffs of Jurassic age in Irkutsk coal-bearing basin. Geol. Geophys., 138-141. (In Russian)

Ludwig, K. R. (2012). User's manual for isoplot 3.75-4.15. Berkeley Geochronol. Cent.

Ludwig, K. R. (1998). On the treatment of concordant uranium-lead ages. Geochim. Cosmochim. Acta, 62, 665-676. https://doi.org/10.1016/S0016-7037(98)00059-3

Ludwig, K. R. and Mundil, R. (2002). Extracting reliable U-Pb ages and errors from complex populations of zircons from Phanerozoic tuffs. Geochim. Cosmochim. Acta, 66, A463-A463.

Meshalkin, S. M., Kizijarov, G. P. and Loseva, L. P. (1983). Volcanogenic and volcanogenicsedimentary rocks of Priikutskaya depression. Geol. Geophys., 150. (In Russian)

Nemchin, A. A. and Cawood, P. A. (2005). Discordance of the U-Pb system in detrital zircons: Implication for provenance studies of sedimentary rocks. Sediment. Geol., 182, 143-162. https://doi.org/10.1016/j. sedgeo.2005.07.011

Odintsov, M. M. (ed.) (1967). Jurassic continental deposits in the south of the Siberian platform. Moscow: Nauka Publ. (In Russian)

Panaev, V. A. (1968). Tectonic evolution of the south of Irkutsk amphitheater in the Mesozoic. (In Russian)

Panaev, V.A. and Nikitina, V.V. (1970). The main differences and the relationship in the development of the Sayayansky and Pribaikalsky Mesozoic troughs. In: Geologiia i poleznye iskopaemye iuga Sibirskoi platformy. Leningrad: Nedra Publ., 68-75. (In Russian)

Rybakov, V.G. and Hobotova, I.I. (1999). State geological map of the Russian Federation 1:200 000. Sheet N-48-XXXIII (Angarsk series). Explanatory letter. (In Russian)

Saks, V. N., Gol'bert, A. V., Dagis, A. S., Mesezhnikov, M. S. and Shackij, S. B. (1981). Explanatory note to the regional stratigraphic patterns of the Mesozoic and Cenozoic of Central Siberia, adopted by the Interagency Stratigraphic Meeting on November 13-17, 1978 in Novosibirsk. (In Russian)

Skoblo, V. M., Lyamina, N. A., Rudnev, A. F. and Luzina, I. V. (2001). Continental Upper Mesozoic of Cisbaikalia and Transbaikalia. Novosibirsk: SB RAS Publ. (In Russian) 
Spears, D. A. (2012). The origin of tonsteins, an overview, and links with seatearths, fireclays and fragmental clay rocks. Int. J. Coal Geol., 94, 22-31. https://doi.org/10.1016/j.coal.2011.09.008

Timofeev, P. P. (1970). Geology and facies of the Jurassic coal-bearing formation in southern Siberia. Moscow: Nauka Publ. (In Russian)

Triplehorn, D. (1990). Applications of tonsteins to coal geology - some examples from western United States. Int. J. Coal Geol., 16, 157-160.

Vermeesch, P. (2018). IsoplotR: A free and open toolbox for geochronology. Geosci. Front., 9, 1479-1493. https://doi.org/10.1016/j.gsf.2018.04.001

Received: February 4, 2020 Accepted: June 15, 2020

Contact information:

Ekaterina A.Mikheeva - mikheeva@crust.irk.ru

Elena I.Demonterova - dem@crust.irk.ru

Valentin B.Khubanov - khubanov@mail.ru

AlexeyV.Ivanov - aivanov@crust.irk.ru

AnastasiaV.Arzhannikova - arzhan@crust.irk.ru

Sergei G. Arzhannikov — sarzhan@crust.irk.ru

Anton V.Blinov - belor_cool@mail.ru 


\title{
Возраст угленакопления в Иркутском бассейне по данным датирования акцессорных цирконов из тонштейна Азейского месторождения (LA-ICP-MS)*
}

\author{
Е.А. Михеева ${ }^{1}$ Е.И. Демонтерова ${ }^{1}$, В.Б. Хубанов ${ }^{2}$, А. В. Иванов ${ }^{1}$, \\ А. В. Аржанникова ${ }^{1}$, С. Г. Аржанников ${ }^{1}$, А.В. Блинов ${ }^{3}$ \\ ${ }^{1}$ Институт земной коры Сибирского отделения Российской академии наук, \\ Российская Федерация, 664033, Иркутск, ул. Лермонтова, 128 \\ 2 Геологический институт Сибирского отделения Российской академии наук, \\ Российская Федерация, 670047, Улан-Удэ, ул. Сахьяновой, 6А \\ ${ }^{3}$ Институт геохимии им. А. П. Виноградова \\ Сибирского отделения Российской академии наук, \\ Российская Федерация, 664033, Иркутск, ул. Фаворского, 1 А
}

Для цитирования: Mikheeva E. A., Demonterova E.I., Khubanov V.B., Ivanov A. V., Arzhannikova A. V., Arzhannikov S. G., Blinov A. V. (2020). Age of the coal accumulation in the Irkutsk Basin based on accessory zircon dating in the Azeisk deposit tonstein (LA-ICP-MS). Вестник Санкт-Петербургского университета. Науки о Земле, 65 (3), 420-433. https://doi.org/10.21638/spbu07.2020.301

Иркутский угольный бассейн расположен на юге Сибирской платформы. Отложения бассейна представлены юрскими континентальными осадками. Еще начиная с 1970-х годов в отложениях бассейна обнаружены вулканогенно-осадочные породы, по которым в настоящее время имеются лишь обрывочные сведения. Ранее возраст отложений Иркутского угольного бассейна устанавливали по биостратиграфическим данным, которые дают довольно широкий временной интервал. Нами изучен разрез черемховской, самой древней юрской свиты Иркутского бассейна на Азейском угольном месторождении (район г. Тулун) с целью получения геохронологических ограничений времени осадконакопления. В работе показано, что тонштейны Иркутского бассейна, преобразованные в каолинит слои вулканического пепла в углях, пригодны для радиоизотопного датирования по акцессорным цирконам. Датирование U-Pb-акцессорных цирконов в тонштейне из промышленного угольного пласта было выполнено с использованием метода LA-ICP-MS. Полученный возраст 187.44+0.45-1.60 млн лет, приходящийся на плинсбах, указывает на период максимального накопления угля в Иркутском бассейне. Это первое радиометрическое определение возраста для времени накопления промышленных угольных пластов в Иркутском бассейне. В отношении региональной стратиграфии полученный возраст согласуется с действующей с 1981 года стратиграфической шкалой и дополняющими ее исследованиями В.М.Скобло, основанными на палинологических данных. Работы, базирующиеся на фитостратиграфических исследованиях, предлагают более молодые оценки (тоар) времени максимального угленакопления в Иркутском бассейне. В контексте палеогеографических реконструкций возраст тонштейна определяет верхнюю границу тектонического периода покоя, что создало условия для озерно-болотных условий седиментации на обширной территории Иркутского бассейна.

Ключевые слова: юрский период, вулканизм, тонштейн, Иркутский угольный бассейн, акцессорные цирконы, U-Pb-датирование.

Статья поступила в редакцию 4 февраля 2020 г.

Статья рекомендована в печать 15 июня 2020 г.

* Работа выполнена при поддержке гранта РФФИ (проект № 18-35-00216). U-Рb изотопно-геохронологические исследования выполнены в ЦКП «Аналитический центр минералого-геохимических и изотопных исследований» ГИН СО РАН г. Улан-Удэ (базовый проект IX.129.1.2., № гос. рег. AАAA-A16-116122110027-2). 
Контактная информация:

Михеева Екатерина Андреевна - mikheeva@crust.irk.ru Демонтерова Елена Ивановна - dem@crust.irk.ru

Хубанов Валентин Борисович - khubanov@mail.ru

Иванов Алексей Викторович - aivanov@crust.irk.ru

Аржанникова Анастасия Валентиновна - arzhan@crust.irk.ru

Аржанников Сергей Геннадьевич - sarzhan@crust.irk.ru

Блинов Антон Валерьевич - belor_cool@mail.ru 